\title{
Konsep Ekonomi Islam dalam Peningkatan Kesejahteraan Mustahiq Melalui Zakat Produktif (BAZNAS) Kabupaten Purworejo
}

\author{
Achmad Nur Sobah ${ }^{1)}$, Fuad Yanuar Akhmad Rifai ${ }^{2)}$ \\ ${ }^{1}$ Hukum Ekonomi Syariah, STAI An Nawawi \\ ${ }^{2}$ Ekonomi Islam, STAI Al Husain \\ *Email korespondensi: cahayapagi87@ gmail.com
}

\begin{abstract}
Abstrak
Tujuan penelitian ini adalah untuk mengetahui pengaruh Zakat, Infaq dan Shadaqah Produktif terhadap pertumbuhan usaha mikro dan kesejahteraan mustahiq di Kabupaten Purworejo, serta juga untuk mengetahui pengaruh pertumbuhan usaha mikro mustahiq terhadap kesejahteraan mustahiq di Kabupaten Purworejo.Penelitian ini termasuk kategori Penelitian eksplanatori atau confirmatory, yakni ingin mendapatkan penjelasan mengenai hubungan antar variabel. Objek yang akan diteliti/dianalisis hubungannya adalah variabel Zakat Infaq Shadaqah (ZIS) produktif dengan variabel usaha mikro dan variabel kesejahteraan mustahik pada BAZNAS Kabupaten Purworejo. Penelitian ini merupakan penelitian kualitatif. Hasil penelitian menunjukkan Zakat, Infaq dan Shadaqah Produktif berpengaruh terhadap pertumbuhan usaha mikro mustahiq di Kabupaten Purworejo, sedangkan Zakat, Infaq dan Shadaqah Produktif tidak berpengaruh terhadap kesejahteraan mustahiq di Kabupaten Purworejo, adapun pertumbuhan usaha mikro mustahiq tidak berpengaruh terhadap kesejahteraan mustahiq di Kabupaten Purworejo. Potensi ZIS di Kabupaten Purworejo sebenarnya cukup besar, apabila mereka menyalurkan zakatnya melalui BAZNAS Kabupaten Purworejo akan terkumpul dana yang lebih besar bagi kemaslahatan ummat.
\end{abstract}

Kata kunci: ZIS produktif, Pertumbuhan, kesejahteraan, mustahiq, BAZ

\begin{abstract}
The purpose of this study was to determine the effect of Zakat, Infaq, and Productive Shadaqah on the growth of micro-businesses and the welfare of mustahiq in Purworejo Regency, and also to determine the effect of the growth of micro mustahiq businesses on the welfare of mustahiq in Purworejo Regency. This research belongs to the explanatory or confirmatory research category, namely want to get an explanation of the relationship between variables. The object to be examined/analyzed for its relationship is the variable Zakat Infaq Sadaqah (ZIS) productive with microbusiness variables and the mustahiq welfare variable in BAZNAS Purworejo Regency. This research is qualitative research. The results showed that Productive Zakat, Infaq, and Sadaqah affected the growth of mustahiq microbusinesses in Purworejo District, whereas Productive Zakat, Infaq, and Sadaqah had no effect on mustahiq welfare in Purworejo District, while the growth of Mustahiq microbusiness did not affect the welfare of Mustahiq in Purworejo District. The potential of ZIS in Purworejo Regency is actually quite large, if they distribute their zakat through BAZNAS Purworejo Regency will raise more funds for the benefit of the Ummah.
\end{abstract}

Keywords: Productive ZIS, Growth, prosperity, mustahiq, BAZ

Saran sitasi: Sobah, A. N., \& Rifai, F. Y. A. (2020). Konsep Ekonomi Islam dalam Peningkatan Kesejahteraan Mustahiq Melalui Zakat Produktif (BAZNAS) Kabupaten Purworejo. Jurnal Ilmiah Ekonomi Islam, 6(03), 521528. doi: http://dx.doi.org/10.29040/jiei.v6i3.1270

DOI: http://dx.doi.org/10.29040/jiei.v6i3.1270

\section{PENDAHULUAN}

Masalah zakat merupakan ibadah yang mengandung dua dimensi yaitu; dimensi hablun min Allah (dimensi vertikal) dan dimensi hablun min annas (dimensi horisontal). Ibadah zakat bila ditunaikan dengan baik, akan meningkatkan kualitas keimanan, membersihkan dan menyucikan jiwa, dan mengembangkan serta memberikan keberkahan harta yang dimiliki. Jika dikelola dengan baik dan amanah, zakat akan mampu meningkatkan kesejahteraan umat, 
mampu meningkatkan etos dan etika kerja umat, serta sebagai pemerataan ekonomi umat. Oleh sebab itu zakat ditetapkan sebagai pilar ketiga Islam sebagaimana ditegaskan dalam hadits:

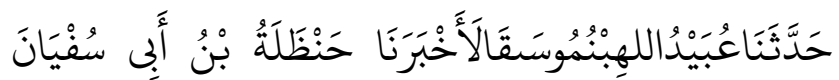

عَنْ عِكْرَةَ بْنِ خَالٍِِ عَنْ ابْنِ عُمَرَ رَضِى اللهُ عَنْهُ قَاَل:

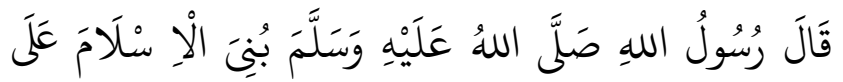

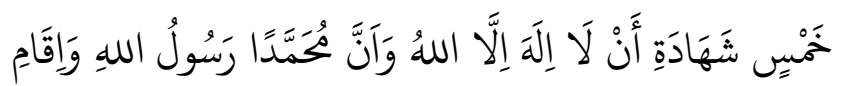

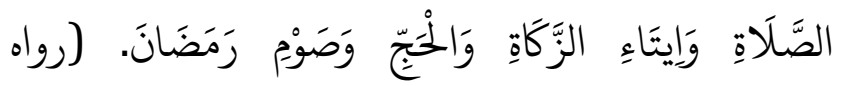

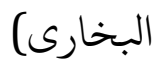

Artinya: "Telah mengabarkan kepada kami, 'Ubaidah bin Musa dari Khandhalah bin Abi Sufyan dari Ikrimah bin Kholid dari Ibnu Umar r.a, katanya Rasulullah SAW. bersabda: "Islam itu dibangun di atas lima dasar: (1) mengakui tiada tuhan selain Allah, dan mengakui bahwa Muhammad itu Rasul Allah.(2) Menegakkan salat (3) Membayar zakat. (4) Menunaikan ibadah haji, dan (5) Puasa bulan Ramadhan."(H.R. al-Bukhari).(bin Ismail AlBukhari, 2006)

Al-Qardlawi menegaskan bahwa Islam tidak hanya menghukum orang-orang yang tidak membayar zakat dengan pembagian separuh kekayaannya atau hukuman-hukuman berat lainnya, tetapi lebih dari pada itu menginstruksikan agar pedang dicabut dan peperangan dinyatakan kepada orang-orang bersenjata yang membangkang membayar zakat.Islam tidak peduli apakah banyak jiwa harus melayang dan darah harus tertumpah untuk mengapa dan melindungi zakat. Ibnu Jauza'i, mengemukakan bahwa orang yang menentang kewajiban zakat, boleh diperangi sampai mereka menyerahkan dan mau membayar zakatnya. Al-Zahabi, mengkategorikan orang yang tidak mau membayar zakat, tergolong pemikul dosa besar.(Hafidhuddin, 2002)

Dari sinilah, lahir dan disahkannya UU No 38 Tahun 1999 tentang Pengelolaan Zakat dapat di usung ketengah harapan masyarakat, sebagai bahan pijakan yuridis dalam mengelola dan mendistribusikan zakat dan merupakan solusi yang harus didukung secara intensif, agar kemudian sistem penanganan dan pengelolaan zakat benar-benar profesional yang nantinya akan lebih berhasil guna mengangkat harkat dan martabat kemanusiaan, sambil kita menutup celah terjadinya berbagai penyimpangan dan penyalahgunaan wewenang dalam pengelolaan zakat. Di dalam undang-undang zakat juga disebutkan jenis harta yang dikenai zakat yang belum ada pada zaman Rasulullah SAW, yaitu "hasil pendapatan dan jasa" atau kata lain yakni zakat profesi. Yusuf Qardlawi menyatakan bahwa diantara hal yang sangat penting untuk mendapatkan perhatian kaum muslimin saat ini adalah penghasilan atau pendapatan yang diusahakan melalui keahliannya, baik keahlian yang dilakukan sendiri, misalnya: dokter, arsitek, ahli hukum, penjahit, pelukis, mungkin juga $d a^{\prime} i$ atau mubaligh, dan lain sebagainya. Bentuk zakat ini merupakan langkah maju menyesuaikan perkembangan zaman.(Kasim, 2014)

Pembentukan Badan Amil Zakat (BAZ) merupakan wujud nyata perhatian pemerintah terhadap kehidupan umat Islam, sehingga diperlukan sebuah mekanisme yang mampu mengalirkan kekayaan yang dimiliki oleh kelompok masyarakat mampu (agniy $\bar{a}$ ') kepada kelompok masyarakat yang tidak mampu (masākin). Menurut ajaran Islam, zakat sebaiknya dipungut oleh negara atau lembaga yang diberi mandat oleh negara dan atas nama pemerintah bertindak sebagai wakil fakir dan miskin. Pengelolaan di bawah otoritas yang dibentuk oleh negara akan jauh lebih efektif pelaksanaan fungsi dan dampaknya dalam membangun kesejahteraan umat yang menjadi tujuan zakat itu sendiri, dibanding zakat dikumpulkan dan didistribusikan oleh lembaga yang berjalan sendiri-sendiri yang tidak ada koordinasi.(Nopiardo, 2016)

Pemerintah juga telah membentuk Undangundang No. 23 Tahun 2011 tentang pengelolaan zakat.Undang-undang memuat tentang pengelolaan zakat yang terorganisir dengan baik, transparan dan profesional dilakukan oleh 'amil resmi yang ditunjuk oleh pemerintah, baik Lembaga Amil Zakat (LAZ) maupun Badan Amil Zakat (BAZ).(Hartatik, 2015)Zakat yang telah dikumpulkan oleh lembaga pengelola zakat harus segera disalurkan kepada para mustahiq sesuai dengan skala prioritas yang telah ditentukan.

Agar Zakat menjadi sumber dana yang dapat dimanfaatkan bagi kesejahteraan masyarakat terutamauntuk mengentaskan masyarakat dari kemiskinan dan menghilangkan kesenjangansosial, perlu adanya pengelolaan zakat secara Profesional dan bertanggung jawabyang dilakukan oleh masyarakat bersama pemerintah (Sumadi,2017) 


\section{Jurnal Ilmiah Ekonomi Islam, 6(03), 2020, 523}

Dari paparan di atas, menjadi sangat penting untuk membahas dana zakat untuk kegiatan produktif akan lebih optimal bila dilaksanakan Lembaga Amil Zakat (LAZ) dan sejenisnya diantaranya adalah Badan Amil Zakat Nasional (BAZNAS) Kabupaten Purworejo yang merupakan lembaga pengelola zakat, infaq dan sedekah yang bersifat nirlaba dan berorientasi penuh pada nilai dasar ibadah dalam mengangkat harkat dan martabat kaum dhuafa menjadi manusia mandiri yang bertaqwa kepada Allah. Zakat center ini memiliki program-program dalam penghimpunan danamaupun penyaluran dananya dan memiliki visi misi serta berbadan hukum yang diperoleh dari Dirjen Bimas Islam Kementrian Agama Republik Indonesia No.DIII/ 568 Tahun 2014.

Badan Amil Zakat Nasional (BAZNAS) Kabupaten Purworejo merupakan organisasi yang terpercaya untuk pengalokasian, pendayagunaan dan pendistribusian dana zakat, mereka tidak memberikan zakat begitu saja melainkan mereka mendampingi, memberikan arahan serta pelatihan agar dana zakat tersebut betul-betul dijadikan modal usaha, sehingga mustahiq dapat menghasilkan pendapatan yang layak dan mandiri serta diharapkan dapat meningkatkan pendapatan usaha mustahiq. Namun dalam hal ini, keberadaan dana zakat yang disalurkan kepada mustahiq belum sepenuhnya efektif, karena dana zakat tersebut selain digunakan untuk usaha, mustahiq juga menggunakan dana zakatnya untuk konsumsi. Dengan segala potensi dan nilai zakat, penulisan yang berkenaan dengan pendayagunaan zakat produktif penting untuk dilakukan. Hal tersebut diharapkan dapat memberikan informasi yang cukup bagi mustahiq mengenai pendayagunaan zakat produktif yang efektif sehingga dapat meningkatkan pendapatan usaha mustahiq.

\section{METODOLOGI PENELITIAN}

Penelitian ini menggunakan pendekatan kualitatif deskriptif. Menurut Sugiyono (2015:147) menyatakan bahwa: Metode deskriptif adalah metode yang digunakan untuk mendeskripsikan atau menggambarkan data yang telah terkumpul sebagaimana adanya tanpa bermaksud membuat kesimpulan yang berlaku untuk umum atau generalisasi.Obyek Penelitian ini adalah BAZNAS Kabupaten Purworejo, selama bulan April sampai dengan Mei 2020.Jenis data yang digunakan dalam penelitian adalah data kualitatif.Sedangkan sumber data yang digunakan dalam penelitian ini adalah data primer dan data sekunder.Dalam rangka pengumpulan data untuk melakukan penelitian ini, peneliti menggunakan teknik pengumpulan data yang meliputi wawancara dan dokumentasi. Ada catatan dalam proses wawancara karena mengikuti protocol kesehatan maka wawancara dilakukan secara online menggunakan media daring.

\section{Pengertian Zakat Produktif}

Definisi zakat produktif akan menjadi lebih mudah dipahami jika diartikan berdasarkan suku kata yang membentuknya. Zakat adalah isim masdar dari kata zaka-yazku-zakah oleh karena kata dasar zakat adalah zaka yang berarti berkah, tumbuh, bersih, baik, dan berkembang. Zakat menurut bahasa adalah tumbuh dan berkembang, berkah dan banyak kebajikan. Menurtut syariat, zakat adalah kewajiban dengan ukuran tertentu pada harta tertentu untuk diberikan kepada kelompok tertentu dalam waktu tertentu dengan beberapa syarat.(Taqiyuddin Abi Bakar bin Muhammad Al-Khusaini, n.d.)

Zakat $m \bar{a} l$ (harta) menurut syara' adalah nama dari sejumlah harta yang tertentu yang diberikan kepada golongan tertentu dengan syarat-syarat tertentu. Dinamakan zakat, karena harta itu akan bertambah (tumbuh) disebabkan berkah dikeluarkan zakatnya dan do'a dari orang-orang yang menerimanya.Sedangkan kata produktif adalah berasal dari bahasa Inggris yaitu "productive" yang berarti menghasilkan atau memberikan banyak hasil.(Hawkins, 1996)

Jadi dapat disimpulkan bahwa zakat produktif adalah pemberian zakat yang dapat membuat para penerimanya menghasilkan sesuatu secara terus menerus dengan harta zakat yang telah diterimanya. Zakat produktif dengan demikian adalah zakat dimana harta atau dana zakat yang diberikan kepada para mustahiq tidak dihabiskan, akan tetapi dikembangkan dan digunakan untuk membantu usaha mereka, sehingga dengan usaha tersebut mereka dapat memenuhi kebutuhan hidup secara terus menerus. Sehingga dapat disimpulkan bahwa zakat produktif adalah zakat yang dikelola dengan cara produktif, yang dilakukan dengan cara pemberian modal kepada para penerima zakat dan kemudian dikembangkan, untuk memenuhi kebutuhan hidup mereka untuk masa yang akan datang.

Yusuf Qardhawi berpendapat bahwa menunaikan zakat termasuk amal ibadah sosial dalam rangka membantu orang-orang miskin dan golongan ekonomi lemah untuk menjunjung ekonomi mereka sehingga 
mampu berdiri sendiri dimasa mendatang dan tabah dalam mempertahankan kewajiban-kewajibannya kepada Allah.(Qardhawi, 1966)

\section{Dasar Hukum Zakat Produktif}

Dalam Al-Qur'an, Hadits dan Ijma' tidak menyebutkan secara tegas dan rinci mengenai dalil zakat produktif, akan tetapi ada celah dimana zakat dapat di kembangkan. Seperti dalam hadits yang diriwayatkan oleh Muslim:

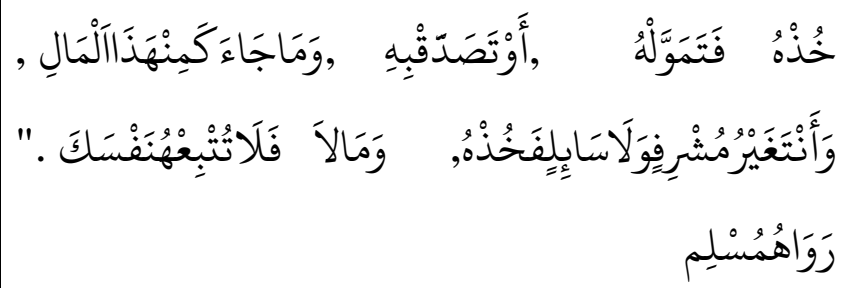

Artinya: "Ambilah dahulu, setelah itu milikilah (berdayakanlah) dan sedekahkan kepada orang lain dan apa yang datang kepadamu dari harta semacam ini sedang engkau tidak membutukannya dan bukan engkau minta, maka ambilah. Dan mana-mana yang tidak demikian maka janganlah engkau turutkan nafsumu”. HR Muslim.(bin Hajjaj, 2002)

Hadits di atas menyebutkan bahwa pemberian harta zakat dapat diberdayakan atau diproduktifkan.Teori hukum Islam menunjukkan bahwa dalam menghadapi masalah-masalah yang tidak jelas rinciannya dalam $\mathrm{Al}$-Quran atau petunjuk yang ditinggalkan Nabi SAW, penyelesaiannya adalah dengan metode ijtihad.Ijtihad atau pemakaian akal dengan tetap berpedoman pada al-Quran dan Hadits.

Dengan demikian berarti bahwa teknik pelaksanaan pembagian zakat bukan sesuatu yang mutlak, akan tetapi dinamis, dapat disesuaikan dengan kebutuhan di suatu tempat. Dalam artian perubahan dan perbedaan dalam carapembagian zakat tidaklah dilarang dalam islam karena tidak ada dasar hukum yang secara jelas menyebutkan cara pembagian zakat tersebut.

\section{Syarat dan Rukun Zakat Produktif}

Adapun syarat dan rukun zakat produktif sama dengan syarat dan rukun pada zakat pada umumnya. Diantara syarat wajib zakat yakni kefardluannya bagi seorang muzakkiialah : (a) Merdeka, yaitu zakat dikenakan kepada orang-orang yang dapat bertindak bebas, menurut kesepakatan para ulama zakat tidak wajib atas hamba sahaya yang tidak mempunyai milik. Karena zakat pada hakikatnya hanya diwajibkan pada harta yang dimiliki secara penuh. (b) Islam, menurut Ijma', zakat tidak wajib atas orang-orang kafir karena zakat ini merupakan ibadah mahdah yang suci sedangkan orang kafir bukan orang suci. (c) Baligh dan Berakal. Zakat tidak wajib diambil atas harta anak kecil dan orang-orang gila sebab keduanya tidak termasuk ke dalam ketentuan orang yang wajib mengeluarkan ibadah seperti sholat dan puasa. (d) Harta yang dikeluarkan adalah harta yang wajib dizakati, diisyaratkan produktif dan berkembang sebab salah satu makna zakat adalah berkembang dan produktifitas yang dihasilkan dari barang yang produktif. (e) Harta yang dizakati telah mencapai nișab atau senilai dengannya, maksudnya ialah nișab yang ditentukan oleh syara' sebagai pertanda kayanya seseorang dan kadar-kadar yang mewajibkan berzakat. (f) Harta yang dizakati adalah milik penuh. Madzhab Hanafi berpendapat bahwa harta benda yang wajib dizakati adalah harta benda yang berada ditangan sendiri atau harta milik yang hak pengeluarannya berada ditangan seseorang atau harta yang dimiliki secara asli. (g) Kepemilikan harta telah mencapai setahun atau telah sampai jangka waktu yang mewajibkan seseorang mengeluarkan zakat misal pada masa panen. (g) Harta tersebut bukan merupakan harta hasil utang.(Daud Ali, 1988)

Adapun rukun zakat produktif adalah mengeluarkan sebagian dari nishab (harta), dengan melepaskan kepemilikan terhadapnya, menjadikannya sebagai milik orang fakir, dan menyerahkannya kepadanya atau harta tersebut diserahkan kepada amil zakat.(Sari et al., 2019)

\section{Macam-Macam Zakat Produktif}

Dalam penyaluran zakat poduktif ada dua macam yaitu zakat produktif tradisional dan produktif kreatif, guna untuk melepaskan fakir miskin kepada taraf hidup yang layak dan dapat memenuhi semua kebutuhannya.

a. Zakat produktif Konvensional adalah zakat yang diberikan dalam bentuk barang-barang produktif.Misalnya kambing, sapi, mesin jahit, alat-alat pertukaran dan sebagainya.(Fitri, 2017) Pemberian zakat dalam bentuk ini akan dapat mendorong orang menciptakan suatu usaha atau memberikan lapangan kerja bagi fakir miskin. Apabla fakir miskin mempunyai ketrampilan berusaha (bekerja) maka mereka diberi zakat yang dapat dipergunakan untuk modal dagang sehingga keuntungannya dapat mereka gunakan untuk memenuhi kebutuhan hidupnya dengan wajar.

b. Zakat produktif kreatif dimaksudkan semua pendayagunaan zakat yang diwujudkan dalam 


\section{Jurnal Ilmiah Ekonomi Islam, 6(03), 2020, 525}

bentuk modal yang dapat dipergunakan, baik untuk membangun suatu proyek sosial maupun untuk membantu atau menambah modal seseorang pedagang atau pengusaha kecil.(Fitri, 2017) Syekh Yusuf Qardawi juga memukakan, dalam bukunya yang fenomenal, yaitu Fiqh Zakat, bahwa pemerintah Islam diperbolehkan membangun pabrik atau perusahaan dari uang zakat untuk kemudian kepemilikan dan keuntungannya bagi kepentingan fakir miskin, sehingga akan terpenuhi kebutuhan hidup mereka sepanjang masa.

Dari pembagian macam-macam zakat produktif diharapkan arah dan kebijaksanaan pengelolaan zakat produktif dapat berhasil sesuai dengan sasaran yang dituju. Adapun maksud arah dan kebijaksanaan pengelolaan zakat adalah segala sesuatu yang berkaitan dengan usaha pemerintah atau pengelola dalam rangka memanfaatkan hasil pengumpulan zakat kepada sasaran dalam pengertian yang lebih luas sesuai dengan cita dan rasa syara', secara tepat guna, efektif manfaatnya dengan sistem distribusi yang serba guna dan produktif sesuai dengan pesan dan kesan syari'at serta tujuan sosial ekonomi dari zakat.

\section{Sistem Pendayagunaan Zakat Produktif BAZNAS Kabupaten Purworejo}

Badan Amil Zakat Nasional (BAZNAS) yang mengelola Amal, Zakat, Infak dan Sedekah, ikut berperan aktif dalam program pengentasan kemiskinan nasional melalui distribusi dan pendayagunaan ekonomi kuat ke ekonomi lemah, keberadaan Badan Amil Zakat Nasional (BAZNAS) Kabupaten Purworejo, juga disambut dengan baik oleh para muzakki yang notabenya bekerja sebagia pejabat, PNS, Polri dan pengusaha, karena menjadikan mudah dan tepat waktu dalam membayar zakat.

Semua kegiatan baik dari pengumpulan sampai pendestribusian dan pendayagunakan zakat terpantau dengan baik karena Badan Amil Zakat Nasional (BAZNAS) Kabupaten Purworejo bekerja dibawah pengawasan Badan Amil Zakat Nasional (BAZNAS) Pusat melalui aplikasi sistem anajemen informasi BAZNAS (SiMBA) yang berbasis online.

Sistem dalam pemberdayaan zakat produktif, tidak semudah dengan sistem pendistribusikan secara konsumtif. Ada beberapa sistem dalam pendistribusian dan pendayagunaan zakat produktif:

\section{a. Sosialisasi}

Sosialisasi dalam Kamus Besar Bahasa Indonesia adalah upaya memasyarakatkan sesuatu sehingga menjadi dikenal, dipahami dan dihayati oleh masyarakat. Kegiatan sosialisasi yang dilakukan oleh lembaga zakat di Indonesia merupakan salah satu cara untuk memberikan pengetahuan mengenai segala sesuatu tentang zakat dan bagaimana cara pengelolaanya dan secara tidak langsung akan membuat muslim yang sudah berkewajiban zakat patuh unuk menunaikan zakat. Yang dimaksud dengan sesuatu disini adalah sesuatu yang berkaitan dengan kepentingan BAZNAS Kabupaten Purworejo, seperti profil, tujuan dan program BAZNAS Kabupaten Purworejo.

b. Pengumpulan

Pengumpulan dimulai dengan penarikan dana zakat dari muzakki yang sudah sesuai niṣab, melaului unit pengumpulan zakat (UPZ), kemudian disetorkan ke BAZNAS.

c. Perencanaan

Perencanaan yang dimaksud adalah merencanakan siapa saja yang akan dikasih dan bagaimana program tersebut berjalan dengan baik, untuk mendapatkan data mustahik yang sesuai dan bisa tepat sasran, maka BAZNAS Kabupaten Purworejo dalam perencanaan ini bekerjasama dengan Pemerintah Daerah (PEMDA) dan Tenaga Kesejahteraan Sosial Kecamatan (TKSK).

d. Pendayagunaan

Sasaran pendayagunaan zakat ini tertuju pada 8 golongan yang sudah diatur dalam al-quran, tetapi dalam BAZNAS Kabupaten Purworejo Mustahik Riqab tidak di programkan, karena tidak ada perbudakan di Indonesia. Mengingat golongan ini sudah tidak ada lagi, maka kuota zakat mereka dialihkan ke golongan mustahiq lain menurut pendapat mayoritas ulama fiqih.

e. Pengawasan

Pengawasan kepada mustahik yang telah diberi bantuan zakat produktif, dengan harapan dana zakat tersebut digunakan dengan baik.

\section{Pendayagunaan ZakatProduktif BAZNAS Kabupaten Purworejo}

Pendayagunaan zakat adalah bentuk pemanfaatan dana zakat secara maksimum tanpa mengurangi nilai dan kegunaannya, sehingga berdayaguna untuk 


\section{Jurnal Ilmiah Ekonomi Islam, 6(03), 2020, 526}

mencapai kemaslahatan umat.Pendayagunaan produktif ada 3 pola, yaitu:

a. Pola Investasi

Pola pendayagunaan zakat adalah dengan menginvestasikan dana zakat. Yusuf Qardhawi dalam Fiqhuz Zakat mengemukakan bahwa pemerintah Islam diperbolehkan membangun pabrik-pabrik atau perusahaan-perusahaan dari dana zakat untuk kemudian kepemilikan dan keuntungannya bagi kepentingan fakir miskin, sehingga akan terpenuhi kebutuhan hidup mereka sepanjang masa. Pengganti pemerintah untuk saat ini dapat diperankan oleh Badan Amil Zakat atau Lembaga Amil Zakat yang amanah, dan profesional.

Permasalahan tentang adanya kemungkinan merugi dalam menginvestasikan danazakat oleh lembaga amil zakat masih belum ditemukan pembahasan dari para ulama klasik. Berikut rekomendasi bagi para amil sebagai upaya mengakomodasi sejumlah pendapat mazhab yang melegalkan investasi dana zakat:Pertama, Amil dapat menginvestasikan dana zakatnya setelah para mustahiq menerima dana zakat terlebih dahulu, jadi dalam hal ini amil hanyaberlaku sebagai wakil dari keseluruhan mustahiq. Semisal jika diinvestasikan pada surat berharga, maka pembelian surat berharga tersebut dilakukan atas nama mustahiq.Kedua, Amil dapat menginvestasikan dana zakatnya setelah mempunyai perhitungan matang pada usaha/ industri yang menjadi objek investasi.

Pola investasi dana zakat oleh Lembaga Amil Zakat dapat diilustrasikan sebagai berikut:

1) Muzakki membayar zakat kepada BAZ/ LAZ

2) BAZ/ LAZ menyalurkan kepada mustahiq untuk menerima haknya

3) Mustahiq mewakilkan haknya dari dana zakat kepada BAZ/ LAZ untuk diinvestikan

4) BAZ/ LAZ melakukan studi kelayakan/ fasibilitas usaha atau perusahaan yang akan disalurkan dana investasi milik mustahiq. BAZ/ LAZ memilihkan usaha yang layak untuk diberikan investasi dari dana zakat sekaligus skema investasinya. BAZ/LAZ mewakili mustahiq untuk menginvestasikan dana tersebut.

5) Investasi menguntungkan, maka dividen/ tingkat pengembalian modal investasi (bagi hasil) didistribusikan kembali pada mustahiq. b. PolaQardulHasan

Pendayagunaanzakat yang mengedepankan pola Qardul Hasan ini dapat diilustrasikan sebagai berikut:

1) Muzakki membayar zakat kepada BAZ/ LAZ.

2) BAZ/ LAZ mendayagunakan kepada mustahiq I untuk dimanfaatkansebagai modal usaha.

3) Usaha untung maka mustahiq mengembalikan modalnya kepada BAZ/ LAZ.

4) Usaha rugi maka mustahiq tidak perlu mengembalikan modalnya.

5) BAZ/ LAZ menerima modal kembali dari mustahiq yang mengalami keuntungan dalam usaha.

6) BAZ/ LAZ memilih menyalurkan kembali kepada mustahiq untuk penambahan modal usaha.

7) BAZ/ LAZ memilih menyalurkan kepada mustahiq II untuk dimanfaatkan sebagai modal usaha, dan begitu seterusnya.

\section{c. Pola Mudarabah}

Berikut pendayagunaan dana zakat dengan Pola Mudarabah:

1) Muzakki membayar zakat kepada BAZ/ LAZ.

2) BAZ/ LAZ mendayagunakan kepada mustahiq I untuk dimanfaatkan sebagai modal usaha.

3) Usaha untung maka mustahiq dan BAZ/ LAZ saling membagi hasil keuntungan.

4) Mustahiq mengambil sejumlah persen keuntungan dan sejumlah persen dikembalikan kepada BAZ/ LAZ berikut modalnya.

5) BAZ/ LAZ menerima modal kembali dari mustahiq berikut keuntungan usaha.

6) BAZ/ LAZ memilih menyalurkan kembali kepada mustahiq untuk modal usaha.

7) BAZ/ LAZ memilih menyalurkan kepada mustahiq II untuk dimanfaatkan sebagai modal usaha, dan begitu seterusnya.

8) Usaha rugi maka mustahiq tidak perlu mengembalikan modalnya.

Pendayagunaandana zakat produktif Badan Amil Zakat Nasional (BAZNAS) Kabupaten Purworejo adalah menggunakan pola sendiri sesuai dengan kemampuan BAZNAS. Adapun pola yang digunakan adalah sebagai berikut:

1. Muzakki membayar zakat kepada BAZNAS

2. BAZNAS mendayagunakan kepada mustahiq untuk dimanfaatkan sebagai modal usaha.

3. BAZNAS mengawasi dalam pengembangan usaha tersebut 


\section{Jurnal Ilmiah Ekonomi Islam, 6(03), 2020, 527}

\section{Pengaruh zakatProduktif Bagi Peningkatan Pendapatan Usaha Mustahiq BAZNAS Kabupaten Purworejo}

Pengaruh zakat produktif bagi mustahik yang diberikan bantuan oleh Badan Amil Zakat Nasional (BAZNAS) Kabupaten Purworejo belum sesuai target pokok yaitu merubah status mustahik menjadi muzakki. Banyak peyebab yang menghambat yaitu latar belakang tingkat pendidikan mustahiq dapat mempengaruhi wawasan dan skill mustahiq dalam mengelola dana dan menjalankan usaha. Oleh karena itu, semakin tinggi tingkat pendidikan mustahiq, pendapatan per kapita mustahiq diharapkan juga akan lebih tinggi karena kemampuannya dalam mengelola dana dan menjalankan usaha.Disisi lain pemberian dana zakat oleh Badan Amil Zakat Nasional (BAZNAS) Kabupaten Purworejo belum mencukupi kebutuhan modal mustahiq akibatnya peningkatan dalam usaha terbilang lambat.

BAZNAS Kabupaten Purworejo memang belum lama didirikan, dari hasil yang dicapainya juga belum begitu banyak, terlihat dengan pendayagunaan zakat produktif yang masih sedikit. program pendayagunaan yang telah di kerjakan yaitu bedah rumah di berbagai tempat seperti di Dusun Tanuprayan Rt/Rw, 03/ 01, Desa Loano, Kecamatan Loano, Kabupaten Purworejo dan Desa Sumbersari, Kecamatan Bayuurip, Kabupaten Purworejo, pengaruhnya sangat signifikan, dengan dibangunnya rumah dengan layak maka mustahiq tidak memikirkan tempat tinggal lagi, tinggal memenuhi kebutuhan ekonomi yang lain.

Dalam pendayagunaan zakat produktif ada juga yang digunakan untuk usaha, dalam hal ini mustahiq berwirauasaha membuat kopyah, usaha ini dilakukam secara mandiri dengan dua orang pembantunya.Dalam perjalanan usahanya semakin hari semakin banyak permintaan partai besar sehingga harus membutuhkan modal yang memadai, seperti membeli perlengkapan jahid dan sebaigainya.Dengan bantuan dana yang diberikan BAZNAS sekarang kebutuhan itu tercukupi dan minimal mengurangi kemacetan dalam beroperasi.

Usaha yang lainpun juga ada yang berjalan baik setelah adanya modal yang diberikan oleh BAZNAS Kabupaten Purworejo, yaitu wirausaha Teh Rosela berbentuk Minuman langsung siap minum. Kendala yang dihadapi tidak lain yaitu modal, karena pemesanan besar, maka diperlukan perlengkapan yang memadahi pula.
Modal sangat dibutuhkan sekali bagi orang-orang yang berwirausaha kecil kecilan, karena dalam memproduksi suatu hal modal yang pertama kali diperhitungkan.

\section{Faktor Pendukung dan Faktor Penghambat}

a. Faktor Pendukung

Faktor pendukung dalam proses pendayagunaan zakat produktif bagi peningkatan pendapatan usaha mustahiq pada BAZNAS Kabupaten Purworejo yaitu dari segi internal BAZNAS sendiri dalam pengelolaan dari sosialisasi sampai pendayagunaan selalu terprogram. Dari eksternal yaitu terbantu dengan keaktifan pegawai Kecamatan, Perangkat Desa dan Masyarakat yang mendukung dan membantu dalam kelancaran program pendayagunaan zakat produktif.

b. Faktor Penghambat

Faktor Penghambat dalam proses pendayagunaan zakat produktif bagi peningkatan pendapatan usaha mustahiq pada BAZNAS Kabupaten Purworejo yaitu dari segi internal BAZNAS sendiri Kurangnya SDM dalam mengoprasionalkan Aplikasi dan kurangnya tenaga kerja, sehingga pengawasan dalam zakat produktif tidak berjalan dengan baik, disamping itu dalam pemberian dana zakat kepada mustahiq hanya sekedarnya, mengingat muzakki yang membayar zakat kepada BAZNAS juga sedikit. Dari segi eksternal kesulitan dalam pencarian data mustahik karena sudah didahului oleh Instansi/Perusahaan dalam pembagian dana, kurangnya SDM musthik sehingga dalam pendayagunaan dana tersebut kurang maksimal.

\section{KESIMPULAN}

Berdasarkan hasil penelitian dan analisis data yang telah dilakukan, maka penulis menyimpulkan bahwa BAZNAS Kabupaten Purworejo sudah ikut berperan aktif dalam peningkatan pendapatan mustahiq, terbukti dengan program yang dikerjakan, seperti memberi modal usaha dan memberi bantuan bedah rumah di berbagai kecamatan di Kabupaten Purworejo, tetapi dalam hasil programnya belum sesuai target awal yaitu merubah mustahiq menjadi muzakki, dikarenakan banyak faktor yang menghambat, baik dari BAZNAS sendiri ataupun dari mustahiq, Tetapi ada peningkatan walaupun belum maksimal. berikut kelebihan dan kekurangan dalam pendayagunaan zakat produktif dalam BAZNAS Kabupaten Purworejo, yaitu pertama, Kelebihan dalam pendayagunaan zakat yang dilakukan BAZNAS Purworejo, hal ini dapat dilihat dari : (a) 
Jurnal Ilmiah Ekonomi Islam, 6(03), 2020, 528

Adanya jalan keluar dalam masalah permodalan yang dialami mustahiq yang diwujudkan dari usahanya yang mengalami perkembangan, yakni usaha Kopyah dan Teh Rosela. (b) Kemampuan mustahiq meningkatkan ekonomi dan dari segi kemakmuran hidup mustahiq mengalami peningkatan, terbukti dengan dibangunkan rumah layak huni diberbagai Kecamatan seperti di Dusun Tanuprayan Rt/Rw, 03/ 01, Desa Loano, Kecamatan Loano, Kabupaten Purworejo dan Desa Sumbersari, Kecamatan Bayuurip, Kabupaten Purworejo. (c) Pemilihan program yang tepat oleh BAZNAS Kabupaten Purworejo yaitu mengadakan permodalan dan bedah rumah.

Kedua, Kekurangan dalam pendayagunaan zakat yang dilakukan BAZNAS Purworejo, hal ini dapat dilihat dari : (a) Belum adanya pengawasan secara intensif dari BAZNAS Kabupaten Purworejo dalam mengawasi mustahiq mengelola dana zakat, akibatnya tidak maksimal dalam hasil usahanya. (b) Kurangnya tenaga kerja dalam BAZNAS Kabupaten Purworejo, yang berdampak pada hasil program yang dicapai. (c) Dana yang masuk di BAZNAS Kabupaten Purworejo belum maksimal, sehingga dalam membantu mustahiq hanya bisa semampunya, dengan begitu hasil yang diperoleh dalam usaha mustahiq juga tidak begitu banyak.

\section{UCAPAN TERIMA KASIH}

Penulis mengucapkan terima kasih kepada semua pihak yang sudah memberikan motivasi, arahan dan doa sehingga penulis dapat menyelesaikan penelitian ini. Jazakumullah Ahsanal Jaza.

\section{DAFTAR PUSTAKA}

bin Hajjaj, M. (2002). Shahih Muslim. Dar Al-Kotob Al-Ilmiyah. bin Ismail Al-Bukhari, M. (2006). Shahih Bukhari. Dar Al-Kotob Al-Ilmiyah.

Daud Ali, M. (1988). Sistem Ekonomi Islam, Zakat dan Wakaf. Universitas Indonesia Press.

Fitri, M. (2017). Pengelolaan Zakat Produktif sebagai Instrumen Peningkatan Kesejahteraan Umat. Economica: Jurnal Ekonomi Islam, 8(1), 149. https://doi.org/10.21580/economica.2017.8.1.18 30

Hafidhuddin, D. (2002). Zakat Dalam Perekonomian Modern. Gema Insani Press.

Hartatik, E. (2015). Analisis Praktik Pendistribusian Zakat Produktif Pada Badan Amil Zakat Daerah (BAZDA) Kabupaten Magelang. Az Zarqa', 7(1), 30-47.

Hawkins, J. M. (1996). Kamus Dwi Bahasa InggrisIndonesia, Indonesia-Inggris. Erlangga.

Kasim, N. M. (2014). Paradigma zakat profesi dalam kehidupan masyarakat gorontalo. Al-Hurriyah, 15,78 .

Nopiardo, W. (2016). Mekanisme pengelolaan zakat produktif pada badan amil zakat nasional tanah datar. Jebi (Jurnal Ekonomi Dan Bisnis Islam), l(2), 185-196.

Qardhawi, Y. (1966). Musykilah al-Faqr Wakaifa Aalajaha Al Islam.

Sumadi, S. (2017). Optimalisasi Potensi Dana Zakat, Infaq, Sadaqah Dalam Pemerataan Ekonomi Di Kabupaten Sukoharjo (Studi Kasus di Badan Amil Zakat Daerah Kab. Sukoharjo). Jurnal Ilmiah Ekonomi Islam, 3(01), 16-26.

Sari, F. K., Safitri, N., Anggraini, W., \& Economics, F. I. (2019). Journal of Islamic Economic Scholar. 1(1), 29-41.

Taqiyuddin Abi Bakar bin Muhammad Al-Khusaini. (n.d.). Kifayatul Al-Akhyar Fi Hall Ghayat AlIkhtishar. Darul Al-Kutub Al-Arabiyyah. 